\title{
Dysmorphococcus variabilis, gen. et sp. nov.
}

\section{BY}

\author{
H. TAKEDA, D.I.C.
}

\section{With fifteen Figures in the Text.}

THE Alga which is here described under the name of Dysmorphococcus variabilis was found in gatherings made during October, I9I5, in a small stagnant pond in Richmond Park, Surrey. It occurred sparingly, associated with some species of Closterium, Cosmarium, Chlamydomonas, Carteria, several species of Euglena (e. g. E. oxyuris, Schmarda, E. spirogyra, Ehrb., \&c.), Lepocinclis (e.g. forms of L. ovum (Stein), Lemm., L. Steinii, Lemm., \&c.), Phacus (e.g. Ph. caudata, Hübn., Ph. longicauda (Ehrb.), Duj., and its var. torta, Lemm., Ph. parvula, Klebs, Ph. pusilla, Lemm., forms of Ph. pyrum (Ehrb.), Stein, Ph. tenuis, Swirenko, Ph. triqueter (Ehrb.), Duj., \&c.), Trachelomonas (e. g. forms of Tr. hispida (Perty), Stein, Tr. rugulosa, Stein, Tr. Stokesiana, Palmer, forms of Tr. volvocina, Ehrb., \&c.), and Vacuolaria virescens, Cienkowski.

Externally the organism under consideration very much resembles the small subglobose form of Trachelomonas volvocina, Ehrb. It can, however, at once be distinguished from the latter, even under a low power of the microscope, by the fact that while it swims about, rotating on its own axis, and, so far as ascertained, always forwards, it presents a more or less angular appearance, due to its irregular shape. An examination under a high power reveals the fact that the organism does not belong to this genus, although there is at least one species (probably new) of Trachelomonas having a shell compressed in a somewhat similar way.

The organism in question possesses a hard, brittle shell, similar in texture to that in the majority of species of Trachelomonas, brown to dark brown in colour, and extraordinarily irregular and variable in shape. The shell easily cracks and breaks up into irregular pieces when subjected to slight pressure, or when fairly strong glycerine is added to the water under the cover-slip. The shell is about $\mathrm{I} \mu$ in thickness, and is ornamented with very minute and regularly arranged granules which resemble the dots in a half-tone print (Fig. $7, f$ ). These granules are in some cases very faint, yet can always be detected, at any rate in all the specimens examined. It

[Annals of Botany, Vol. XXX. No. CXVII. January, 1916.] 
I52 Takeda.-Dysmorphococcus variabilis, gen. et sp. nov.
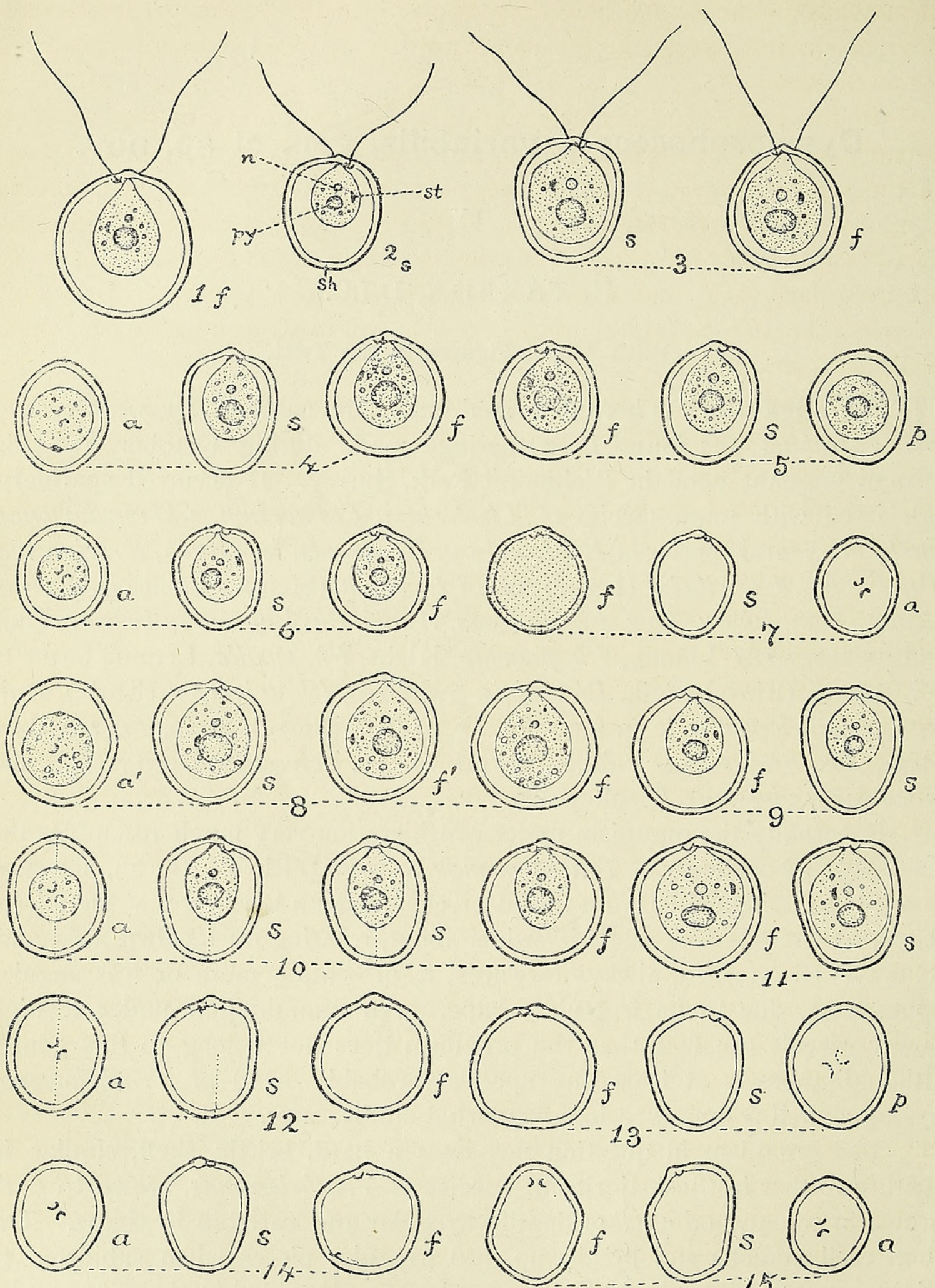

13
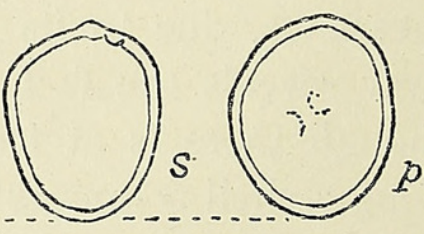

Figs. I-I 5. Dysmorphococcus variabilis, Tak., gen. et sp. nov. All $\times \mathrm{r}, 000 . \quad a=$ anterior view ; $a^{\prime}=$ oblique anterior view ; $f=$ front view ; $f^{\prime}=$ oblique front view ; $p=$ posterior view ; $s=$ side view $; n=$ nucleus $; \not y=$ pyrenoid $; s h=$ shell $; s t=$ stigma (= eye-spot). Figs. 7 , I $2-\mathrm{I} 5$ represent empty shells. Stigma is not represented in Fig. IO, which was drawn from a specimen the colour of which had faded after fixation and mounting. 
can be positively stated that they are granules, and not scrobiculations. It may also be mentioned here that the shell usually causes the interference of light on its margin, in the same way as in many smooth species of Trachelomonas.

In the front view the shell appears as a rule more or less round or broadly ovate ( $f$ in Figs. I, $3^{-12}$ ). In rarer cases it is more or less quadrangular ( $f$ in Figs. I $3, I_{4}$ ), and very seldom it is irregularly rhomboidal (Fig. I5, $f$ ). In the side view it is more or less pentagonal in form, narrowing towards the base. The end views ( $\alpha$ and $p$ in Figs. $4-8$, I0, I 2-I 5 ) are irregularly oval, and show two cilial apertures. The part of the shell between the two apertures projects very slightly, forming a very small beak-like protuberance.

In many cases, especially in the specimens with distinct granules, a faint yet conspicuous line (dotted) on the long axis of the shell in both side and end views is noticeable (cf. $a$ and $s$ in Figs. IO, I2). This dotted line extends round the base of the shell, but gradually disappears when the upper region of the shell is reached. The only explanation I can offer at present is that this line is due to a coalescence of some of the granules on the surface of the shell. It is probably brought about by the fact that as the shell gradually gets narrow towards its base, the granules, which are, as already described, very regularly distributed, find in the lower region of the shell less room for their arrangement, consequently some of them may be expected to become confluent. This is assumed to have occurred along the median line, resulting in the production of the dotted line above referred to.

This probably accounts for the fact that the dotted line is always circumbasal, but never encircles the whole shell.

As to the question whether this dotted line indicates that the shell consists of two more or less equal halves and that the line may be regarded as a suture, I am not prepared to give an answer. Only once a piece of shell was found, which had been apparently broken along this line, but this isolated occurrence may perhaps have been accidental.

The cilial apertures above referred to are very minute, being just large enough for the necessary play of the flagella, and have no thickening on the margin. It seems that they are more or less funnel-shaped, with the narrow end directed towards the apical beak of the protoplast, to which the flagella are attached. On this account, it usually happens that the apertures are viewed more or less obliquely, and they then appear as semicircles.

The apertures lie in a plane which is not parallel to the long axis of the anterior end view of the shell, but cuts the median line at an angle of about $45^{\circ}$ (cf. $a$ in Figs. $7,8,10,12,14$, and $p$ in Fig. I3), so that each half of the shell appears to have one of the apertures belonging to it. For this reason, only one of the apertures is distinctly visible in either the front 


\section{I54 Takeda.-Dysmorphococcus variabilis, gen. et sp. nov.}

view or the side view, except in the case of an extremely irregular specimen, such as that delineated in Fig. I5. The direction of the plane, including the apertures, is practically constant, hence in the front view the aperture is seen on the left-hand side of the beak, and in the side view on the right (compare the front and side views with the end views).

The size of the shell varies as much as the shape does. Fig. I represents the largest specimen I have examined, and Fig. 7 the smallest. The range of size is therefore $I_{4-I} 9 \mu$ high, I $3^{-1} 7 \mu$ broad (i. e. in the front view), and IO-I $4 \mu$ thick (as seen in the side view).

The actual body of the Alga inside the shell is often considerably smaller than the shell, a clear space being present between them. In all the specimens examined the body never completely fills up the shell. The space is an actual one, and is not homologous with the so-called 'space' found in Sphaerella, Chlamydomonas, Carteria, and some other allied genera, in which the 'space' is really the gelatinous part of the cell-wall. It is probable that the space in Dysmorphococcus contains water in which the organism lives. In one case I observed a living specimen, the shell of which became accidentally cracked and broken, presumably by pressure of the cover-slip. The organism, which had been vigorously swimming, did not seem to suffer at all, and as soon as a little water was added, which enabled the monad to move more freely, it resumed its propulsion and actively swam with the broken shell hanging on to the body.

The protoplast is roughly pear-shaped, tapering towards the apex into a short colourless beak (Figs. I-6, 8-II). At this end of the protoplast the algal body is apparently in connexion with the apex of the shell. Two flagella of equal length are attached to the beak, and emerge through the apertures above described. So far as could be ascertained, the protoplast has no definite cell-wall, ${ }^{1}$ but, unlike that of Polyblepharideae, it does not show amoeboid movements. There is a single chloroplast which is urceolate and occupies practically the whole of the body. In most cases the chloroplast is pale green and contains a few minute granules, the nature of which has not been determined. In one case (Fig. 8) a larger number of granules was observed, and this character, like the occurrence of an exceptional colour in the chloroplast of many Chlamydomonads, is probably due to special physiological conditions. A small discoidal stigma (eye-spot) is present, and has a peripheral position, being external to the chloroplast and forming a slight prominence on the surface of the protoplast ( $\alpha$ in Figs. $4,6,8)$. Its position varies to some extent; in some specimens it occurs in the middle portion of the body, while in others it is nearer the apical beak. A pyrenoid of fairly large size is always present near the base of the chloroplast, or in some cases at a slightly higher level. The pyreno-crystal and amylaceous envelope can easily be differentiated by means of the usual stains, including

1 The shell is not regarded as a cell-wall. 
iodine. The nucleus, which is very small, is situated at the bottom of the central protoplasmic mass within the hollow of the chloroplast. So far no contractile vacuoles have been observed.

As already mentioned, the protoplast varies in size, being as a rule much smaller than the shell, but sometimes almost filling up the lumen of the latter. The smallest protoplast observed measures $8 \mu$ in length and $6 \mu$ in transverse diameter, while the largest one reaches $12 \mu$ in length and Io $\mu$ in transverse diameter. The variation in size of the protoplast does not run parallel with the size of the shell; thus a small shell may be found to possess a protoplast of relatively large size, while a large shell may contain a small protoplast. The variations in the size of the protoplast are probably connected with its growth, the proportional size of the protoplast being presumably an index of the age of the specimen.

It is much to be regretted that we have no knowledge regarding the reproduction of this Alga. ${ }^{1}$ It may, however, be presumed that the protoplast, when it has reached a certain size, divides into possibly two or four, and gives rise to daughter-cells within the original shell. Hence the examples with a relatively large protoplast may perhaps be regarded as a stage preceding asexual reproduction. At a certain stage after division of the protoplast into daughter-cells, the shell no doubt breaks and liberates the young naked individuals, each of which sooner or later must secrete a shell for itself. It seems improbable that the daughter individuals become provided with shells within the mother-shell.

Since the life-history of this Alga is not known, nothing precise can be stated as to the affinity of this peculiar organism. However, so far as the vegetative characters are concerned, Dysmorphococcus undoubtedly possesses all the essential features of the Volvocaceae. Amongst the described members of this family, the organism under consideration appears to be closely related to Coccomonas, ${ }^{2}$ which, however, differs in having a definite cell-wall and a large single aperture in the shell for the emergence of both of the flagella. For the present it may be convenient to place our new genus in the Phacoteae, a sub-family of the Volvocaceae. Since this new alga possesses two cilial apertures in the shell, it may be suggested that the organism should be compared with Isococcus, ${ }^{3}$ which has been described as having an envelope of a similar nature. An examination of the original preparations of Isococcus has convinced me that there is no relationship

1 No stage of division has been found either in nature or in the laboratory cultures, the latter having been not very successful. As the author is returning to Japan shortly, it is impossible for him to continue his investigations. Further study of this singular organism, in particular with regard to reproduction, is therefore left to the hands of those botanists who are in a position to obtain fresh material. The pond in which the organism was found lies near the south-eastern corner of Conduit Wood and can easily be reached by entering the Park through Richmond Gate.

${ }^{2}$ Cf. Wille, in Engler and Prantl, Pfanzenfam., i. 2, p. 40, Fig. 22, M, N (1897), and also his Nachträge to Chlorophyceae (I909).

3 Fritsch, in New Phytologist, vol. xiii, p. 34I (19I4). 
whatsoever between these two organisms, except in so far as they both belong to the Volvocaceae. As a reinvestigation of Isococcus, in conjunction with Professor F. E. Fritsch, is in progress, further remarks upon this organism will be dealt with later in a separate paper.

\section{DiAGNOSIS.}

Dysmorphococcus, ${ }^{1}$ Tak., gen. nov. Cellulae vegetativae nudae, libere natantes, polo apicale in rostrum brevissimum decoloratum producto et flagellis binis aequilongis quam corpore cellulae sesqui- vel subduplo longioribus praedito, in tegumento rigido fragilique, brunneo, plerumque valde distento, aperturis binis instructo, nascentes. Chromatophora singula, viridis, urceolata ; stigma parvum, parietale; nucleus fere centralis vel paulo anterior; vacuolae contractiles carentes(?). Propagatio ignota. Grege Coccomonadis collocandum esse videtur, sed a qua tamen membrana cellulae destituta aperturis flagellorum binis differt. Species unica.

Dysmorphococcus variahilis, Tak., sp. nov. (Figs. I-I 5). Cellulae pyriformes, stigmate in parte media vel subanteriore, pyrenoide singulo basali vel submedio, subconspicuo; tegumentum, brunneum vel atrobrunneum, granulis minutissimis regulariter distributis ornatum, valde polymorphum, a fronte visum rotundato-ovatum, raro subquadrangulare, rarissime irregulariter rhomboidale, a latere visum pentagonum, basin versus subcuneatum plus minus attenuatum, a vertice visum subovale, utraque aperturas flagellorum minutas, margine non incrassatas manifestans. Tegument. long. I4-19 $\mu$, lat. I $3-17 \mu$, crass. IO-I $4 \mu$.

Hab. In stagno prope silvam Conduit Wood, in Richmond Park, Surrey (Oct., I9I5)

I take this opportunity of expressing my sincere thanks to Professor G. S. West, of Birmingham, for his helpful suggestions, and I also tender my thanks to Sir David Prain, C.M.G., the Director of the Royal Botanic Gardens, Kew, for allowing me to carry out the present investigation in the Jodrell Laboratory. I am also deeply indebted to Mr. L. A. Boodle, the Keeper of the Jodrell Laboratory, for his kindly criticism and valuable help.

\footnotetext{
1 A berry of no particular shape is the derivational meaning of the word.
} 


\section{$2 \mathrm{BHL}$ Biodiversity Heritage Library}

Takeda, H. 1916. "Dysmorphococcus variabilis, gen. et sp. nov." Annals of botany 30, 151-156. https://doi.org/10.1093/oxfordjournals.aob.a089581.

View This Item Online: https://www.biodiversitylibrary.org/item/237452

DOI: https://doi.org/10.1093/oxfordjournals.aob.a089581

Permalink: https://www.biodiversitylibrary.org/partpdf/320103

\section{Holding Institution}

Smithsonian Libraries

\section{Sponsored by}

Biodiversity Heritage Library

\section{Copyright \& Reuse}

Copyright Status: Not in copyright. The BHL knows of no copyright restrictions on this item.

This document was created from content at the Biodiversity Heritage Library, the world's largest open access digital library for biodiversity literature and archives. Visit BHL at https://www.biodiversitylibrary.org. 